\title{
Convenience Space Planning For Secondary Education In Delta State
}

\author{
Obasi Kenneth K. \\ Opene Benedict
}

\begin{abstract}
The study was on convenience planning in the provision of secondary education in Delta State. It adopted the descriptive survey design. The population was all the 891 secondary schools in the state. Through stratified random sampling technique, a sample size of 225 schools was drawn (public -115, private -110). A checklist was used to obtain data for the study. The data generated were analysed using percentage. The study revealed that convenience space was adequately planned in both public and private secondary schools, though with minor differences in some areas. The study recommended that they should be a collaborative framework between the ministry of education and the schools both public and private to ensure strict compliance with convenience space specified standards. This will help improve those areas where there are deficiencies in convenience space planning.
\end{abstract}

\section{INTRODUCTION}

Education has been proven over the years to be the bedrock of any country's development. This is the major reason why government and the private sector are investing heavily in education as a veritable platform for socio-economic development. This is the basis for human capital thesis which states that the productive capacity of individuals is significantly developed through education and training. Consequently, an educated population is a productive one. Education is therefore a strategic investment for national development through the acquisition of relevant skills, knowledge and attitudes. It requires a lot of financial and infrastructural commitment and it is a continuous process that cuts across all the three levels of education. However, the concern of this study is secondary education.

Secondary education is the bridge connecting primary and tertiary education. It is designed to equip the students to either transit to the tertiary level or to exit into the world of work with some basic skills, competencies, knowledge and attitudes. This obviously makes secondary education very critical in the entire education process, since its basic objective is double barreled. The main reason why acquisition of secondary education in Nigeria is important is because, the curriculum of primary education is not sufficient in helping the child to acquire certain educational qualities such as lasting literacy, communication skills, language fluency, and numeracy skills (Chinelo,2011). In other words, it is at this level of education that the additional knowledge and skills needed to help the child excel at the tertiary level are inculcated into him/her. This however cannot be achieved without school plant.

School plant is the sum total of the buildings, equipment, other facilities, including the surroundings where teaching and learning takes place. The school plant includes all permanent, semi-permanent and moveablestructures in the school. Agabi(2002) remarked that school plant forms the hardware through which the educational curriculum (the software) is transmitted to the individuals being educated. By implication, all facilities, that is, all material resources in the school form the school plant.He equally maintained that school plant includes the physical structure, the furniture, the equipment, and other material resources that directly 
or indirectly aid teaching and learning. School plant, according to Abraham (2013), implies all facilities and equipment within the school which are used by the members of the school community; to him, all the physical structures in the school are within this category. Enaohwo and Eferekeya as cited by Maduagwu and Nwogu (2006:14) asserted that "school plant is the entire scope of the infrastructural facilities provided in the school for the purpose of educating the child". School plant therefore is the life wire of the teaching-learning process, as well as other non-teaching activities carried out within the process of education delivery in the school.

However, the provision of these facilities, even in their right quantities and qualities, is not sufficient nor does it automatically guarantee the desired results. The planning of the facilities is not only critical but decisive to ensuring the desired results. Planning entails the determination of goals to be achieved, the resources required, in their right quantities and qualities, the determination of responsibilities, the actual implementation of assigned tasks and the continuous evaluation of the process vis-a -vis the goal to be realized. Ipso facto, school plant planning requires that the educational goals and objectives already determined should provide the basis and the guiding platform for the determination of the school plant to be provided, where and how they are to be sited. In other words, the curriculum to be implemented, through which the educational goals and objectives are to be realized, must be the guiding factor. The curriculum necessarily, determines the facilities to be provided to ensure relevance and effectiveness.

Planning is an essential aspect of human development. There can be virtually no meaningful progress without careful planning, i.e. thinking through what to do, how to do it and where to do it, when to do it and who to do it. It is considered before doing and concerns the process of what is to be done to reach a valid goal (Igbozuruike, 2016). In other words, planning is neither intuitive nor haphazard activities to be done but a deliberately, arranged and directed course of actions towards achieving predetermined goals.

Educational planning implies a global approach which brings to light short comings and needs that hitherto had been ignored or unknown. By putting the defects in proper perspective, it ensures a balanced distribution of energies and resources both short and long term actions.

Educational planning is not a goal or an end in itself, rather it is an instrument to examine the problems involved in educational change which compels the educational planner to look for the socio-economic and political factors necessary for the successful actualization of the stated objectives. Indeed, its significance, thus seen as preparing and subsequently evaluating a set of decisions of future actions aimed at achieving specific sets of goals (UNESCO, 2005).

From the above, it is clear that educational planning is a sort of a system analysis to the problems of education with the aim of resolving the educational problems, so as to make the system effective and efficient.

School plant planning which is an integral aspect of educational is planning, denotes the proper distribution of educational facilities within the school premises. Adequate planning of the available educational facilities significantly ensures effective and efficient teaching and learning. This is why Adesina in Abraham (2013) posited that the quality of education that our children receive has direct relevance to the availability or lack of physical facilities and overall atmosphere where the learning takes place. Thus, for the presence of quality education in the school system, the school plant has to be adequately planned and provided for. 
Convenience space planning is one aspect of school plant planning which is often ignored. Space for convenience consists of toilets, cafeteria, kitchen, dormitories, custodian sheds and stores. Convenience space in schools serves to accommodate the non - classroom needs of students and staff. These spaces must be carefully planned, taking into consideration such factors as the current and future enrollment rates in the educational system and the different methods of instruction. Classrooms can be added to a building without much difficulty, but spaces for convenience are often difficult to expand at an expense after the initial construction. Over crowded support facilities are inefficient and may neglect much of the effectiveness of the instructional areas.

Convenience space planning plays a significant role in the teaching and learning process. The extent to which these may enhance better teaching and learning depends on the location, structure and facilities within the school premises (Ajayi\&Yusuf, 2010). While emphasizing the importance of space for convenience planning for student academic performance, Jaiyeoba and Atanda (2011) stated that their availability and accessibility to students could also result in better performance and if otherwise, the opposite will be the case. As a result, spaces for convenience in schools need to be properly planned as they play fundamental roles in the improvement of the teaching and learning process.

Lionel (2006) emphasized that school planners should be aware of the possibility of multipurpose use of support spaces. An initial step in this direction is an analysis of the basic function of each support space required to fulfill the educational specification in general. Spaces such as custodial quarters, kitchen and rooms for mechanical plant equipment and operations do not lend themselves readily to multipurpose use, unless they can be used for classes relating to their specific function. For instance, the use of the kitchen for service program, such spaces as the cafeteria, gymnasium and the auditorium may be combined in several ways. For example, the cafeteria can serve as a lunchroom and auditorium, the gymnasium can also serve as auditorium, the area can serve all three of the above functions and the auditorium can be combined with a theatre. Sirengo (2015), maintained that dual use of these areas requires careful planning and usually places some restrictions on their adequacy for specific purposes. Once the basic function of each support space has been determined, planners should consult the architect in order to integrate these spaces into the total project.

In planning these spaces, the planners ensure that they are relevant within the school. For instance, the school canteens should always have nutritional foods, intoxicating beverages are strictly prohibited. Also the toilet system must be such with washing facilities and preferably with the toilet for boys and that for girls located far apart.

However, people have been complaining about poor placed space for convenience such as toilet, cafeteria and so on in some secondary schools. This scenario whereby convenience spaces are not properly planned may likely have a negative impact on the effective delivery of education.

The Philippines Department of Education (PDE), (2016), insisted that every school should have toilet facilities within the school premises; with toilet for boys and girls located separately. It recommended the following standards:

Boy's toilet: 1 seat per 100 students, 1 seat designed for disabled students, 1 detached urinal per 100 students per 50 students, 1 seat designed for disabled students. 1detached urinal per 50 students It also recommended the provision of hand washing facilities approximate to play grounds, gardens, school canteens and toilets. 
On the other hand, the Virginia Department of Education (VDE) (2010), recommended that school cafeteria should have a dining room with 11-14 square feet per student and rectangular tables with stacking chairs. However, the dining room floor areas is determined by the number of seats needed based on a total enrollment. While the size of a dining room is determined by dividing the total enrollment by the number of launch seating times the square footage per student as mentioned above, in the same vein, dining rooms under 3,000 square feet should have a ceiling height of 12 feet, while dining rooms over 3,000 square feet should have a ceiling height of 14 feet.

The recommended kitchen layout design, receiving area, area for storage, of recycling, space for food preparation, serving lines, area for food and non-food storage, employee's locker, toilet facilities and all other proposed equipment of the general kitchen is 1,000 square feet plus one square foot times the total enrollment, Virginia Department of Education (VDE) (2010).

Odufowokan (2011) observed that convenience space planning facilitates the delivery of effective secondary education. This position was corroborated by Yakubu (2017) in the findings of his study that convenience space planning aids academic performance.

The relevance of convenience space planning in the delivery of quality education at all levels, is therefore not in doubt. This is because they serve the non-classroom needs of both students and staff, and impacts indirectly on the teaching-learning process. The proper planning of convenience space in schools is therefore imperative for the effective and efficient realization of set educational goals and objectives.

\section{Statement of the Problem}

The importance of convenience space in schools for the attainment of set educational goals and objectives cannot be overemphasized because it impacts both directly and indirectly on the teaching-learning process. Ipso facto, its planning is imperative. Despite the essential role the convenience space plays in the overall health of a school, it is sad to observe in many schools today that either the facilities are grossly inadequate and or are sited based on convenience. For instance, some preliminary observations suggested that convenience spaces such as toilet facilities are not properly sited and sanitized to prevent spread of germs and diseases in the school community.

It is not therefore strange sometimes to see students demonstrate violently against school authorities, engage in truancy or are involved in certain deviant behaviour that impact negatively on the life of the student or the school. Such a situation sometimes compromises the safety and security of the students and staff, thereby, impeding on the effective administration of the school. This is precisely the concern of the researchers. What is therefore the level of planning of the convenience space in secondary schools in Delta State?

\section{Purpose of the Study}

The purpose of the study was to determine the extent to which convenience space was planned in secondary schools in Delta State.

\section{Research Question}

To what extent is convenience space planned in secondary schools in Delta State? 


\section{METHODOLOGY}

The study adopted the descriptive survey design.

The population of the study comprised all the public and private secondary schools in Delta state. They were eight hundred and ninety one number (public $=453$; private $=438$ ). The sample size for the study was 225 secondary schools (public $=115$; private $=110$ ). This was $25 \%$ of the population. The stratified random sampling technique was adopted to draw the sample. Each of the zones in the state serves as a stratum. They were twelve educational zones in the states. From each of the strata a simple random sampling technique was used to draw the sample size. The instrument was a checklist used to ascertain the rate at which convenience spaces were planned in both technique and private secondary schools. Facilities or spaces that had properly sited ratings of $X \geq 60 \%$ were rated satisfactory whereas those that have below $60 \%$ were rated unsatisfactory. Data generated were analysed using percentage.

\section{Research Question}

\section{DATA PRESENTATION}

To what extent is convenience space planned in secondary schools in Delta State?

Table 1: The result of a checklist on the extent for which convenience space is planned in public and private secondary schools in Delta state.

\begin{tabular}{|l|l|l|l|l|l|l|l|}
\hline S/n & $\begin{array}{l}\text { Description } \\
\text { item }\end{array}$ & \multicolumn{2}{l|}{ Public schools } & \multicolumn{2}{l|}{ Private schools } \\
\hline & & $\begin{array}{l}\text { Properly } \\
\text { sited \% }\end{array}$ & Rank & Remarks & $\begin{array}{l}\text { Properly } \\
\text { sited }\end{array}$ & Rank & Remarks \\
\hline 1 & Cafeteria & 51 & 6 & Unsatisfactory & 60 & 5 & Satisfactory \\
\hline 2 & Toilet & 72 & 1 & Satisfactory & 78 & 1 & Satisfactory \\
\hline 3 & Dormitories & 71 & 2 & Satisfactory & 73 & 2 & Satisfactory \\
\hline 4 & Custodian sheds & 62 & 3 & Satisfactory & 58 & 6 & Unsatisfactory \\
\hline 5 & Relaxation room & 61 & 4 & Satisfactory & 64 & 4 & Satisfactory \\
\hline 6 & Water & 56 & 5 & Unsatisfactory & 66 & 3 & Satisfactory \\
\hline
\end{tabular}

Table 1 above shows the percentage measure of the extent convenience space was planned in public and private secondary schools in Delta state. The analysis of checklist data as shown above revealed that item 2, 3, 4 and 5 had properly sited ratings of $72 \%, 71 \%, 62 \%$ and $61 \%$ for public schools and item 1, 2, 3, 5 and 6 had properly sited ratings of $60 \%, 78 \%, 73 \%, 64 \%$ and $66 \%$ for private schools. These high properly sited ratings indicated that toilet facilities, dormitories and relaxation rooms, were properly planned and adequately provided for students and staff of both public and private schools. Item 1 and 6 had properly sited ratings of $51 \%$ and $56 \%$ for public school whereas $60 \%$ and $66 \%$ for private schools. This implies that cafeteria and water were properly planned and provided for in private secondary schools and not in public secondary schools. Item 4 which examine the extent custodian sheds were planned revealed $62 \%$ for public and $58 \%$ for private. This indicated that it was properly planned in public schools and not in private schools.

\section{DISCUSSION OF FINDINGS AND IMPLICATIONS}

As revealed by the findings, convenience space was both in public and private secondary schools as shown by the percentage ratings. This implies that convenience spaces such as toilet, canteens, relaxation rooms, dormitories etc. are planned and properly located in the public and private schools. 
These findings are different from the findings of Sani (2008) who observed that convenience spaces are not properly planned in secondary schools in Kebbi State. He further stated that private schools in particular did not observe the economy with space and appropriateness of location of convenience facilities. However, the study carried out by Yakubu (2017) revealed that spaces of convenience were highly planned in both public and private schools. This suggests that government effort towards ensuring that both public and private schools are properly planned is yielding good results. This is an evidence that shows that convenience space is an essential aspect of school life.

\section{CONCLUSION}

On the basis of the above findings, the study therefore concluded that convenience space is planned in both public and private secondary schools in Delta State, though some of the aspects of the convenience space are not properly provided and planned.

\section{RECOMMENDATIONS}

There should be a collaborative framework between the ministry of education and the schools, both in public and private to ensure strict compliance with convenience space specified standards. This will help improve those areas where they are deficiency in convenience space planning.

Also, policy provisions on convenience space in schools should be strictly enforced to ensure strict compliance in both public and private schools.

\section{References}

Abraham, N.M. (2013) Educational Administration in Nigeria. Port Harcourt: Pan Unique Publishers.

Agabi, O.G (2002). Classroom Management.Bori: Fedsbary.

Chinelo, O.D. (2011). Falling Standard in Nigeria education: Traceable to proper skills acquisition in schools. Research Journal on Organizational Psychology And Educational Studies, 28 (Ii), 325-335.

Federal republic of Nigeria (2014). National Policy on education Lagos: NARDC

Fillion, J. (2006). Manual for planning and construction of school buildings. New Hampshire Department of Education council: NH Department of education press.

Igbozuruike, I. U. (2016). Alternative strategies for financing public secondary schools in a declining economy in Imo state. Nigerian journal of Educational Administration and planning. 16(1) 119 - 130.

Jaiyeoba, A.0 and Atanda, A. I. (2011) school Quality factors and secondary student's Achievement in Mathematics in South-Western and North Central Nigeria. The African Symposium: Journal of the African Educational Research Network. Vol 11 (1): 91-100

Maduagwu, S.N. \&Nwogu, U.J. (2006). Resource Allocation and management in education. Port Harcourt: Chadik. Odufowokan, B.A. (2011). School plant as correlate of students' academic performance in southwest Nigeria secondary schools. International journal of business administration 2(2) , 82-90.

Philippines Department of Education (2016). Educational Facilities Manual. Pasigcity: Author.

Sani, D.M. (2008). Schools plant lighting, acoustic, layout and student's academic performance in Kebbi State secondary school. European scientific journal of education. 9(25), 1857-17881.

Sirengo, J.L. (2015). School factors as correlates of secondary students. Achievements in mathematics in Bumgoma country, Kenya. International Journal of Educational Investigations. 2(10) 27 - 34.

Virginia department of education (2010). Guidelines for schools facilities in virgina. Retrieved from http://www.amzom.com

Yakubu .S. (2017). Space for convenience planning and Academic performance of Secondary School students in Oyo state, Nigeria. Journal of education and practice 8, (74) 73-78. 